\title{
EAST ASIAN SPECIES OF GENUS STEREODON (BRID.) MITT. (PYLAISIACEAE, MUSCI) IN RUSSIA
}

\section{ВОСТОЧНОАЗИАТСКИЕ ВИДЫ РОДА STЕRЕОDОN (BRID.) MITТ. (PYLAISIACEAE, MUSCI) ВО ФЛОРЕ МХОВ РОССИИ}

\author{
Olga M. AFONINA ${ }^{1} \&$ ELENA A. IGNATOVA ${ }^{2}$ \\ ОЛЬГА М. АФОНИНА ${ }^{1}$, ЕЛЕНА А. ИГНАТОВА ${ }^{2}$
}

\begin{abstract}
In the course of revision of the genus Stereodon for Moss Flora of Russia, five East Asian species are recognized; most of them are little known in Russia, and therefore are commented on in the present paper. Stereodon dieckei is reported for Russia for the first time. Confirmed collections of S. densirameus (Ando) Afonina \& Ignatova, comb. nov. are reported as all the previous records of this species were based on wrongly identified specimens. Descriptions, illustrations and comparisons with similar species, and distribution maps in Russia, are provided. In addition a key for identification of Stereodon and superficially similar taxa in Russia is given.
\end{abstract}

Резюме

При изучении рода Stereodon для Флоры мхов России в коллекциях с Дальнего Востока было выявлено пять восточноазиатских видов, большинство из которых относится к редким и малоизвестным в России. Stereodon dieckei приводится для России впервые. Stereodon densirameus (Ando) Afonina \& Ignatova, comb. nov. ранее приводился для Дальнего Востока ошибочно, однако теперь установлены достоверные метонахождения. Для выявленных видов даны описания, иллюстрации, сравнение с близкими видами, карты распространения. Кроме того, приводится ключ для определения видов рода Stereodon и таксонов, внешне сходных с видами этого рода, встречающихся в России.

\section{INTRODUCTION}

The genus Stereodon was in wide use at the end of the XIX and beginning of the XX century, but later most authors considered it as a synonym of Hypnum and transferred most of its species to the latter genus. However recent phylogenetic studies demonstrated that Hypnum cupressiforme, the type of the genus Hypnum, is not related to most of the species referred to this genus. Therefore the genus Stereodon was resurrected by Ignatov \& Ignatova (2004), to accommodate the main part of the species of Hypnum.

Thirteen species of Stereodon were reported for the territory of Russia (Ignatov, Afonina, Ignatova et al., 2006). This genus is considered to be diffi- cult to identify because of the great variability of its species and the vague limits between them.

The revision of sect. Hamulosa (within the genus Hypnum) in Russia was published recently by Afonina (2004), and the European species Stereodon fertilis was discussed by Afonina \& al. (2006). However, the group of species with East Asian distribution known in the Russian Far East remains neglected, except $S$. calcicola that was recently reported as new for Russia and briefly discussed by Afonina \& Cherdantseva (2007).

The revision of Stereodon collections from the main bryological herbaria of Russia (IRK, LE, MHA, MW, SASY, VLA) and new materials collected by Ignatov in 2006-2007 revealed three East

1 - V. L. Komarov Botanical Institute Rus. Acad. Sci., Prof. Popov Str., 2, St. Petersburg, 197376 Russia - Россия 197376, Санкт-Петербург, ул. Проф. Попова, 2, Ботанический институт им. В. Л. Комарова РАН.

2 - Biological Faculty, Moscow State University, Moscow 119991 Russia - Россия 119991 Москва, Московский государственный университ, Биологический факультет, каф. геоботаники. 


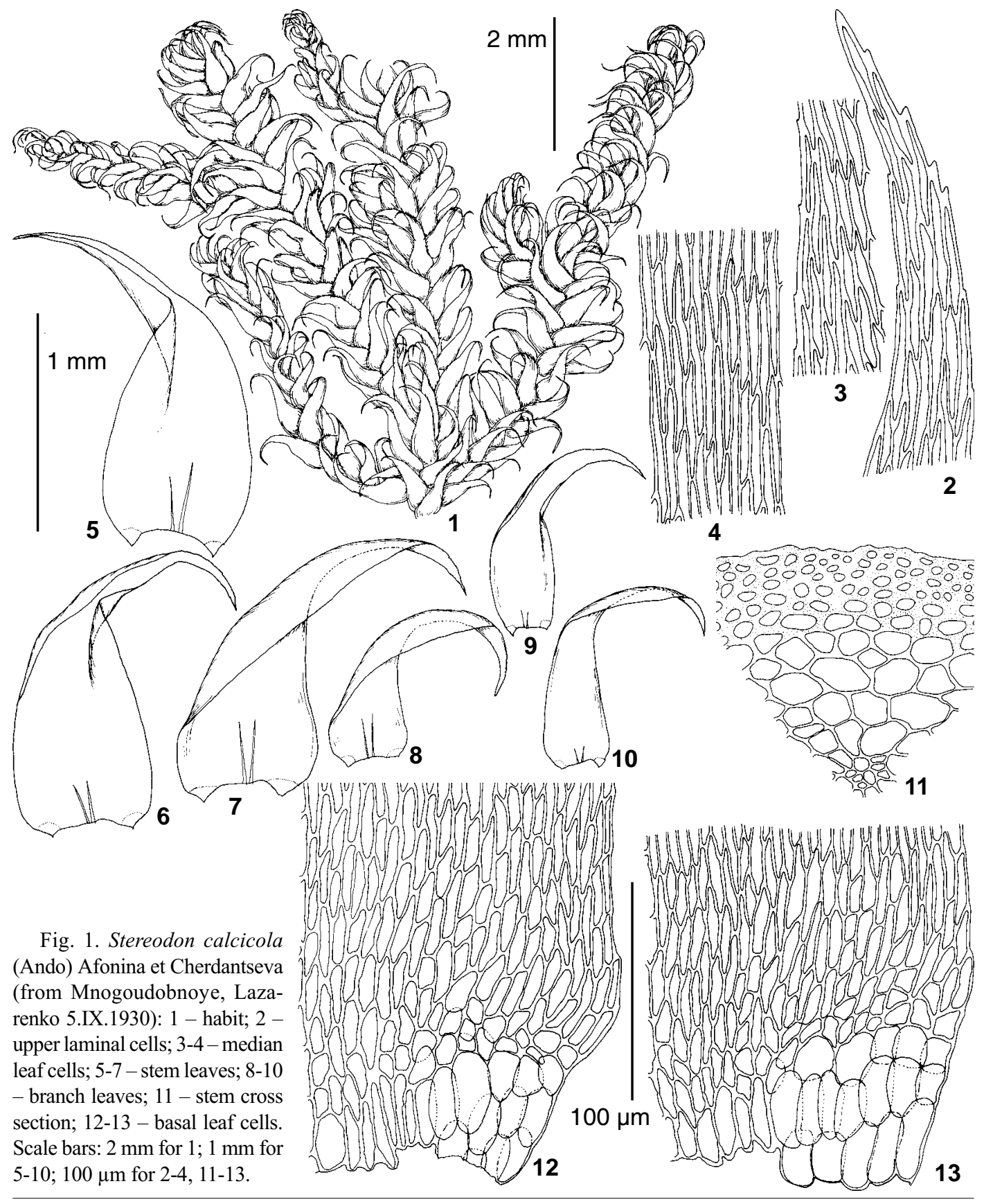

Asian species in the Russian Far East (Stereodon calcicola, S. densirameus, S. dieckei), and two East Asian-North American species ( $S$. fauriei and S. plumaeformis). Stereodon dieckei is reported for the moss flora of Russia for the first time. All earlier records of $S$. densirameus in Russia (Bardunov, Cherdantseva, 1982; Ignatov \& Afonina, 1992) were based on misidentified specimens and this species was excluded from the Russian territory (Ignatov, Afonina, Ignatova et al., 2006). However, in the present paper we reestablish this species due to new specimens found during this study. New localities are reported for other East Asian species of the genus. One more species, $S$. tristoviridis, was also revealed in the Russian Far East, but is discussed separately in the genus $P y$ - 
laisiadelpha (Afonina et al., 2007).

To make this overview more useful, a key is given for all species of Stereodon known in Russia, with the addition of superficially similar species of Hypnum, Breidleria, Drepanium, and Pylaisiadelpha.

1. Stereodon calcicola (Ando) Afonina et Cherdantseva, Bot. Zhurn., 92(11): 1760. 2007.

Figs. 1, 7

Hypnum calcicola Ando, J. Sci. Hirosima Univ. Ser. B, Div. 2(Botany) 8: 167, "calcicolum". 1958.

Plants moderately robust, in dense yellowishgreen turfs. Stems prostrate, strong, red-brown, to $5 \mathrm{~cm}$, irregularly and loosely pinnately branched; rounded in cross-section, without thinwalled epidermal cells; cortical cells in 3-4 layers, thick-walled; central strand weakly differentiated. Branches 3-10 mm long, slightly complanate. Pseudoparaphyllia triangular-lanceolate. Stem leaves $2.0-2.5$ x 0.55-0.70 mm, falcate-secund to circinate, triangular-lanceolate or oblonglanceolate, somewhat rounded at insertion, gradually tapering and narrowly acuminate, not plicate; margins serrulate distally; costa double, distinct, sometimes reaching 1/3 of leaf length. Branch leaves smaller, more shortly acuminate, 1.1-1.4 x $0.4 \mathrm{~mm}$. Laminal cells linear, 40-60 x 2.5-3.0 $\mu \mathrm{m}$; cells at leaf insertion yellowish-brown, thickwalled, porose; alar region distinctly excavate, consisting of enlarged, hyaline, inflated cells and 3-4 rows of small subquadrate supra-alar cells. Autoicous. Perichaetial leaves lanceolate, to 5.5(-8.0) $\mathrm{mm}$ long, strongly plicate, indistinctly serrate distally. Seta reddish-brown, 2.0-3.0 cm. Capsule 1.2-1.8 mm long, inclined to horizontal, oblong, slightly curved. Operculum conic-apiculate. [Exostome teeth $0.75 \mathrm{~mm}$ long, endostome $0.85 \mathrm{~mm}$ long; cilia 2-3. Spores 15-22 $\mu \mathrm{m}$.] (Description of peristome is given according to Ando, 1958). One specimen seen from Primorsky Territory with immature sporophytes.

SPECIMENS EXAMINED: Primorsky Territory: Shkotovo Distr., Mnogoudobnoye Village, 5.IX.1930 Lazarenko s.n. (VLA, LE); Partizansk Distr., Lozovyj Range, Chandolaz Mt., Ignatov \#07-1 (MHA).

Distribution. Stereodon calcicola was previously known as an endemic of Japan, in Honshu, Shikoku and Kyushu (Ando, 1958; Noguchi, 1994).
It was recently reported from Shkotovo District of Primorsky Territory (Afonina \& Cherdantseva, 2007), and a new locality is revealed in Partizansk District. It grows on limestone outcrops.

Differentiation. The main diagnostic characters of Stereodon calcicola are (1) autoicous sexual condition; (2) growth on calcareous rocks; (3) absence of stem hyalodermis; (4) alar group welldelimited, consisting of large thin-walled hyaline alar cells and small subquadrate supra-alar cells. In habit Stereodon calcicola is similar to S. plumaeformis; the latter species differs in the larger size of the plants, more shortly acuminate stem leaves and dioicous sexual condition. S. calcicola shows some superficial resemblance to $S$. fauriei; however, the latter species has smaller plants, a less differentiated alar group and a partial hyalodermis in stem cross-section, and it grows mainly on rotten logs while $S$. calcicola is restricted to limestone.

2. Stereodon densirameus (Ando) Afonina \& Ignatova, comb. nov. Figs. 2, 6

Hypnum densirameum Ando, J. Sci. Hiroshima Univ. Ser. B, Div. 2 (Botany). 8: 1. 1957.

Plants medium-sized, in flat yellowish-brown turfs. Stems prostrate, to $5 \mathrm{~cm}$, regularly and very densely pinnately branched; thin-walled hyaline epidermal cells in cross-section not clearly differentiated and visible only at places; cortical cells in 3-5 layers, thick-walled, yellowish-brown; central strand slightly developed. Branches 3-5 mm long, slightly complanate. Pseudoparaphyllia triangular-lanceolate or palmate. Stem leaves 1.6-2.0 x $0.35-0.50(-0.70) \mathrm{mm}$, falcate, triangular-lanceolate or oblong-lanceolate, abruptly narrowed at the insertion, gradually tapering, longly acuminate, not plicate; margins recurved at leaf base, serrulate distally; costa double, usually distinct. Branch leaves smaller, 1.3-1.7 x 0.3-0.4 mm, falcate. Laminal cells linear, (40-)50-70 x 2-4 $\mu \mathrm{m}$; alar region consisting of few large, thin-walled, hyaline cells and more numerous small, thickwalled supra-alar cells. Autoicous. Perichaetial leaves lanceolate, plicate, abruptly and shortly acuminate, $2.0-2.5 \mathrm{~mm}$ long, serrate distally; costa double. Seta 2.0-3.0(-4.0) cm. Capsule 1.5-2.0 mm long, horizontal, oblong, curved. Operculum conic-obtuse with indistinct mamillate beak. Exostome teeth to $0.5 \mathrm{~mm}$ long, yellow proximally. 


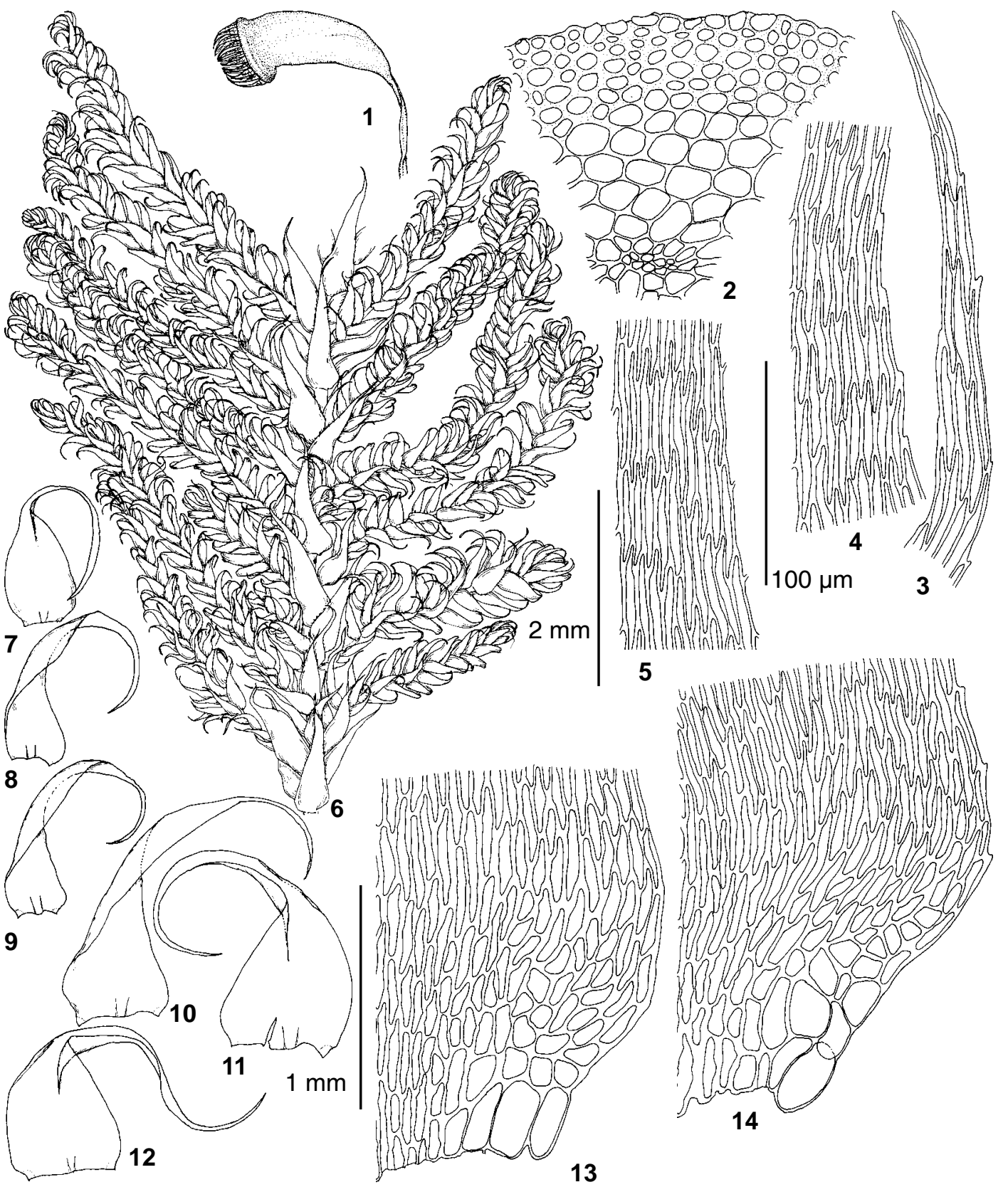

Fig. 2. Stereodon densirameus (Ando) Afonina \& Ignatova (from Kunashir, Ignatov \#06-1307): 1 - capsule; 2 stem cross section; 3 - upper leaf cells; 4-5 - median leaf cells; 6 - habit; 7-8 - branch leaves; 910-12 - stem leaves; 13-14 - basal leaf cells. Scale bars: $2 \mathrm{~mm}$ for 1, 6; $1 \mathrm{~mm}$ for 7-12; $100 \mu \mathrm{m}$ for 2-5, 13-14.

Basal membrane of endostome to $1 / 2$ height of exostome teeth; cilia 2-3. Spores 14-17 $\mu$ m.

SPECIMENS EXAMINED: Khabarovsk Territory: Sovgavan' Distr., Avcha River, 29.VII.1972 Cherdantseva s.n. (LE); Primorsky Territory: Dal'negorsk Distr., Potajnoj spring, 6.VII.1970 Cherdantseva s.n. (LE); Chuguevka Distr., Verkhne-Ussuriiskij scientif- ic station, 31.VIII.1974 Cherdantseva s.n. (LE); Sakhalinskaya Province: Kuril Islands, Kunashir, NW slope of Ruruj Mt., Dal'nij Creek, Ignatov \# 06-1056, 06-1973, 06-1307 (MHA, LE).

Distribution. Stereodon densirameus is distributed in Japan (Hokkaido, Honshu, Shikoku, Kyushu). In Russia this species is very rare, known 
only from Khabarovsk and Primorsky Territories and Kunashir Island. The previous record of this species for Primorsky Territory based on a specimen from Chuguevka District (Bardunov, Cherdantseva, 1982) belongs to $S$. fauriei. Stereodon densirameus grows in fir-spruce forests on rotten logs.

Differentiation. Stereodon densirameus is recognized by the densely pinnate branching, stem leaves cordate at base, with excavate alar group consisting of few large hyaline thin-walled cells and numerous small subquadrate supra-alar cells. This species is close to $S$. fauriei, the difference between them is discussed under the latter species. In habit $S$. densirameus is also similar to $P y$ laisiadelpha tristo-viridis; the latter species differs in the dioicous sexual condition and non-excavate alar group consisting of few large, inflated, "bubble-like", rather thick-walled cells and few smaller supra-alar cells.

\section{Stereodon dieckei (Renauld \& Cardot) Broth. \\ Figs. 3, 6}

Hypnum dieckei Renauld et Cardot, Bot. Centralbl. 44: 473. 1890. Stereodon pulchroalaris Broth. et Yas., Oefv. Finsk. Soc. Foerh. 62A(9): 39. 1921.

Plants medium-sized to large, in soft green to yellowish-green or often reddish-brown (almost as in Scorpidium revolvens) turfs. Stems redbrown, prostrate, to $4-8 \mathrm{~cm}$, subpinnately branched; thin-walled, hyaline epidermal cells distinct in cross-section; cortical cells in 3-4 layers, thickwalled, brownish-red; central strand slightly differentiated. Branches short, hooked above. Pseudoparaphyllia broadly lanceolate to ovate. Stem leaves $1.0-1.5 \times 0.45-0.50 \mathrm{~mm}$, falcate to circinate, oblong triangular-ovate, gradually tapering, acuminate, red-brownish at insertion, not plicate; margins narrowly recurved to mid-leaf, serrulate distally; costa weakly differentiated. Branch leaves smaller, with short acumen. Laminal cells 40-60 × 3-4 $\mu \mathrm{m}$, with slightly thickened walls, subporose; basal cells shorter, broader, strongly porose, brownish-red; alar group narrow, consisting of 2-3 enlarged, inflated, thin-walled, hyaline, bulging cells along leaf margin and few quadrate supra-alar cells. Dioicous. Perichaetial leaves lanceolate, to $5.0 \mathrm{~mm}$ long, plicate. Seta yellowishbrown to reddish-brown, to $5.0 \mathrm{~cm}$. Capsule 3.0-4.5 mm long, inclined to horizontal, more or less cylindric. Operculum conic-apiculate. Exostome teeth $0.65 \mathrm{~mm}$ long, yellowish-brown proximally, basal membrane of endostome extending to $1 / 3$ the length of exostome teeth; cilia of endostome rudimentary. Spores 20-30 $\mu \mathrm{m}$. [Description of sporophyte is given according $\mathrm{H}$. Ando (1958) with some additions from Japanese specimens studied in LE.]

SPECIMENS EXAMINED: Sakhalinskaya Province: Kuril Islands: Kunashir, NW slope of Ruruj Mt., Dal'nij Creek, Ignatov \# 06-1307 (MHA, LE); Kunashir, Tyatya Volcano, Ignatov \# 06-1843 (MHA, LE).

Distribution. Stereodon dieckei occurs in Japan (Hokkaido, Honshu, Shikoku, Kyushyu), it is also known in the Aleutians, north-western North America. In Russia this species is reported for the first time from Kunashir Island. It grows on boulders near creek and on rocks in elfin woodland.

Differentiation. The main diagnostic characters of Stereodon dieckei are (1) clearly differentiated hyalodermis in stem cross-section; (2) reddish-brown, thick-walled and porose cells at leaf base; (3) narrow alar group consisting of 2-3 large, hyaline, thin-walled, bulging cells along leaf margin and few quadrate supra-alar cells; (4) growth in moist habitats. This species is close to $S$. callichrous (Brid.) Braithw. and is distinguished from it by somewhat shorter and broader, serrulate leaf apex, reddish-brown color of cell walls at the leaf base, larger and usually inclined capsules, and the larger size of spores (20-30 $\mu \mathrm{m}$ in $S$. dieckei, 12-15 $\mu \mathrm{m}$ in $S$. callichrous), and the more regular branching. In habit $S$. dieckei is also similar to Calliergonella lindbergii (Mitt.) Hedenäs which is distinguished by weakly falcate leaves with broader acumen, and the alar group more strongly delimited, consisting of more numerous hyaline thin-walled cells.

4. Stereodon fauriei (Cardot) Ignatov \& Ignatova, Arctoa 11 (Suppl. 2): 855. 2004. Figs. 4, 6

Hypnum fauriei Cardot, Beih. Bot. Centralbl. 17: 41. 26. 1904.

Plants medium-sized, in soft green to yellowish-green turfs. Stems prostrate, to $5(-8) \mathrm{cm}$, regularly and rather densely branched; thin-walled hyaline epidermal cells indistinct and visible only at places in stem cross-section; cortical cells in 34 layers, thick-walled, yellowish-brown; central strand slightly differentiated. Branches 3-7 mm long, slightly complanate. Pseudoparaphyllia lan- 


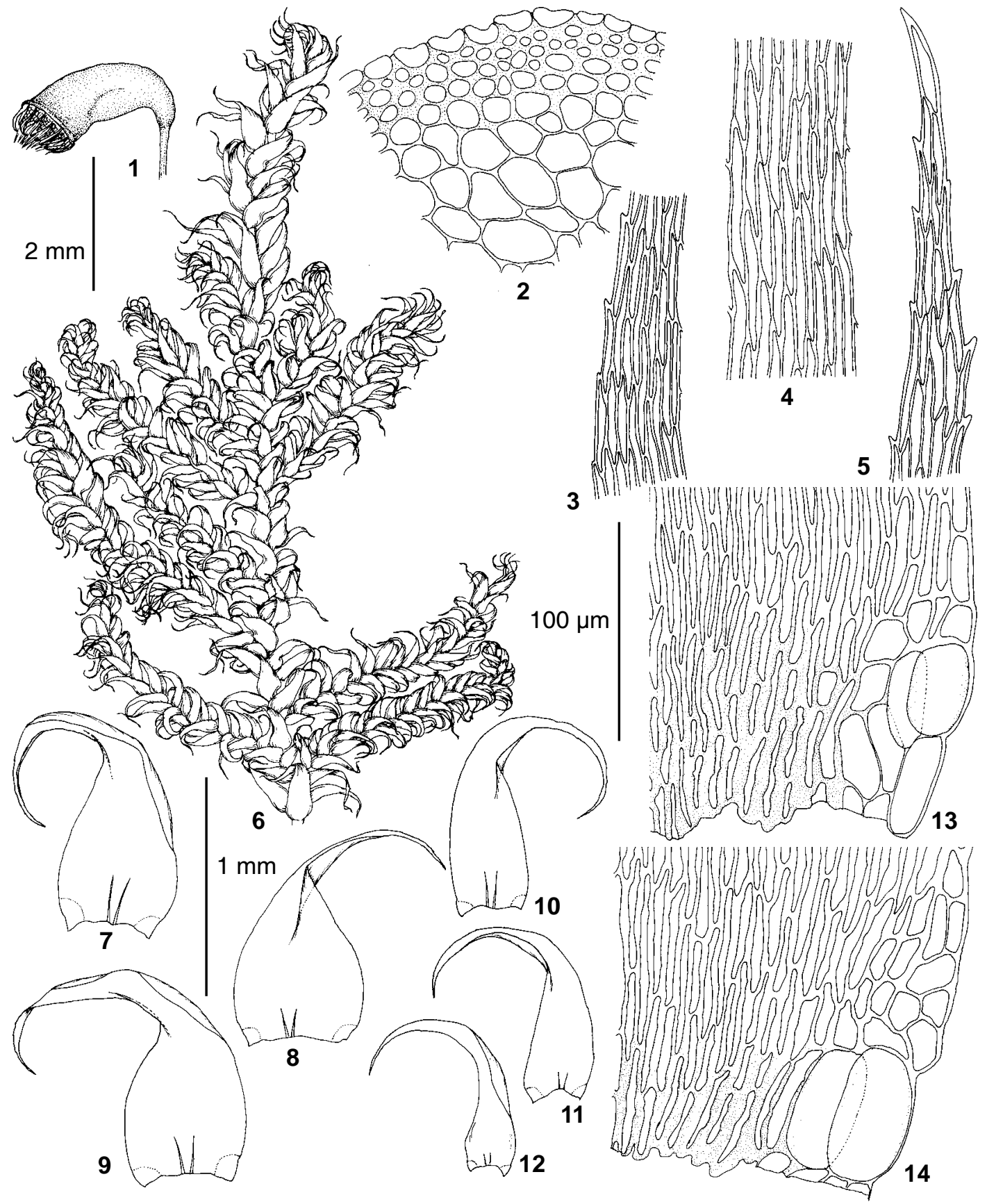

Fig. 3. Stereodon dieckei (Renauld \& Cardot) Broth. (from Kunashir, Ignatov \#06-1417): 1 - capsule; 2 - stem cross section; 3-4 - median leaf cells; 5 - upper leaf cells; 6- habit; 7-9 - stem leaves; 10-12 - branch leaves; 13 14 - basal leaf cells. Scale bars: $2 \mathrm{~mm}$ for 1,$6 ; 1 \mathrm{~mm}$ for 7-12; $100 \mu \mathrm{m}$ for 2-5, 13-14.

ceolate to subulate. Stem leaves $1.4-2.5 \times 0.4-0.8$ $\mathrm{mm}$, falcate to circinate, triangular-ovate, slightly narrowed to the insertion, gradually tapering, narrowly acuminate, not plicate; margins serrulate distally; costa double, distinct, sometimes reaching $1 / 3$ of leaf length. Branch leaves smaller, 1.1-1.4 x 0.3-0.4 mm. Laminal cells $50-80 \mathrm{x}$ 4-5 $\mu \mathrm{m}$; alar cells enlarged, hyaline, forming distinctly (in stem leaves) and almost indistinctly (in branch leaves) delimited group. Autoicous. Sporo- 


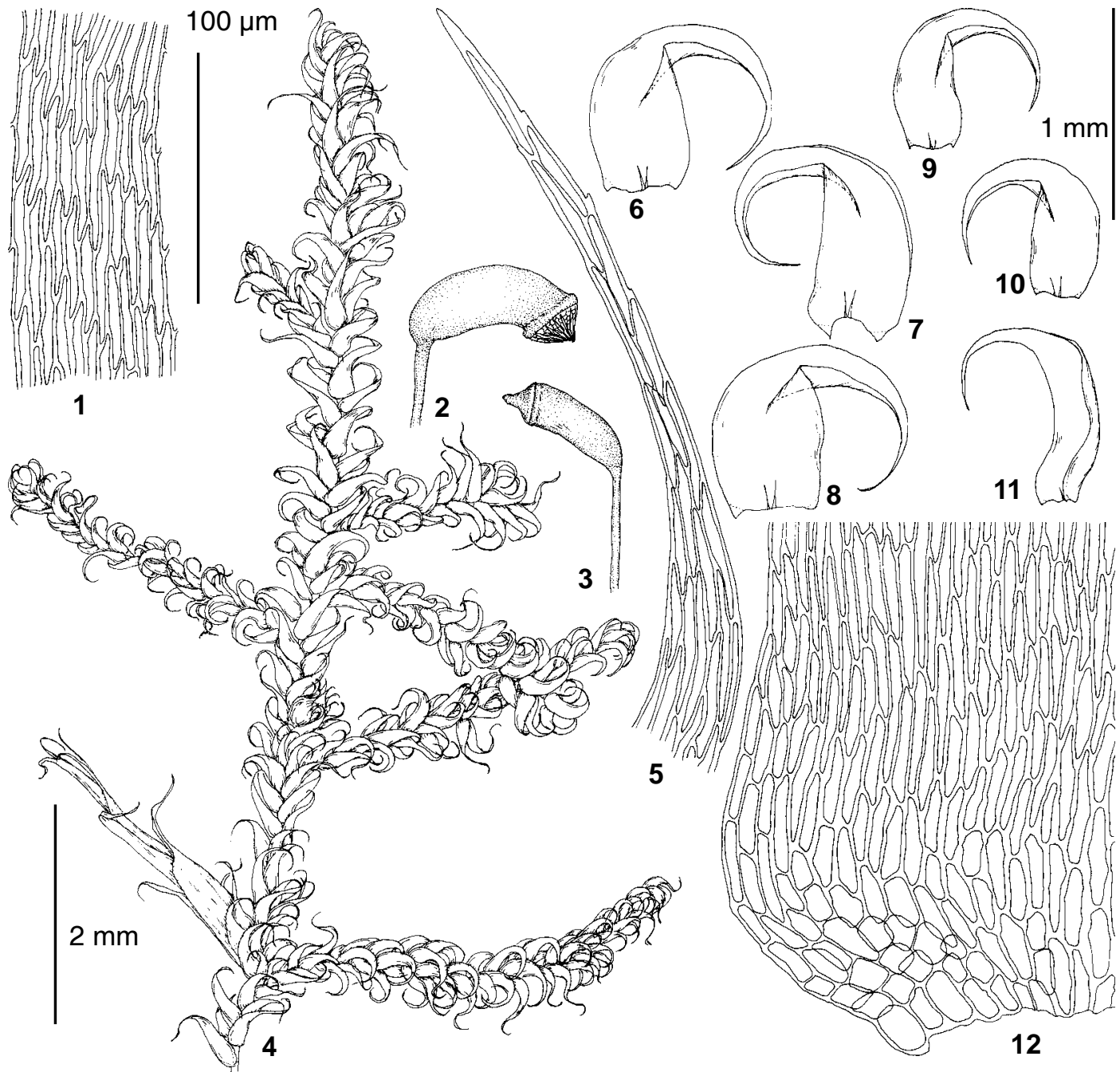

Fig. 4. Stereodon fauriei (Cardot) Ignatov \& Ignatova (from Yakutia, Aldan Distr., Gobuk, Usanova 17.VII.1960): 1 - median leaf cells; 2-3 - capsules; 4 - habit; 5 - upper leaf cells; 6-8 - stem leaves; 9-11 -branch leaves; 12 - basal leaf cells. Scale bars: $2 \mathrm{~mm}$ for $2-4 ; 1 \mathrm{~mm}$ for $6-11 ; 100 \mu \mathrm{m}$ for $1,5,12$.

phytes frequent. Perichaetial leaves lanceolate, with filiform acumen, 2.0-3.0(-5.0) x $0.6 \mathrm{~mm}$, plicate, serrulate distally; costa double, indistinct. Seta yellowish-brown to reddish-brown, 1.5-4.0 $\mathrm{cm}$. Capsule 2.0-3.0 mm long, arcuate. Operculum conic, with short beak . Exostome teeth 0.55 $\mathrm{mm}$ long, distinctly serrate in the upper third; imperfectly striolate below; densely papillose in the middle; with rare minute papillae in the upper part. Endostome teeth $0.65 \mathrm{~mm}$ long; cilia nodose. Spores $15-22 \mu \mathrm{m}$.

SPECIMENS EXAMINED: Altai Republic: Chemal, 450 m alt., Ignatov \# 34/231 (MHA); Chichelgan Range, 800 m alt., Ignatov \# 0/1725 (MHA); Kairu
Creek, 1000 m alt., Ignatov \# 15/144 (MHA); Karagai (Teletskoye Lake), $440 \mathrm{~m}$ alt., Ignatov \# 0/1710 (MHA); Kobukhta (Teletskoye Lake), $450 \mathrm{~m}$ alt., Ignatov \#0/ 1712 (MHA); Yailyu (Teletskoye Lake), $480 \mathrm{~m}$ alt., Ignatov \# 0/631 (MHA); Yakutia: Olekminsk Distr., near Torgo Village, Krivoshapkin \# 0019 (SASY); Aldan Distr., Gobuk, 17.VII.1960 Usanova s.n. (SASY). Amurskaya Province: Zeya River Basin, Tukuringra Range, 18.VIII.1909 Prokhorov \& Kuzeneva \# 220,223 (LE); Zeya State Reserve, Teplyj Creek, 15.VIII.1980 L. Abramova \#164 (MW). Khabarovsk Territory: Muhena River Basin, 3.VIII.1926 Neimark \# 11 (LE); Komsomol'skij Reserve, Ambarnaya Pad', 20.VI.1986 Cherdantseva s.n. (VLA, LE); Verkhnebureinskij Distr., Dusse-Alin' Range, Bureinskij Reserve, Levaya Bureya River, 23.VIII.1989 Petelin s.n. (LE); same, Vank- 
ish, 700 m, Ignatov \# 97-105, 97-217 (MHA); same, Lan, 610 m, Ignatov \# 97-215, 97-216 (MHA, LE); same, Umalta-Makit, 550 m alt., Ignatov \# 97-103, 97218 (MHA); Verhnebureinskij Distr., Bureya River, Seregekta Creek, 530 m alt., Ignatov \#97-104 (MHA); same, Tastakh Creek, 430 m alt., Ignatov \# 97-219 (MHA, LE); same, Shakhtinsky, $370 \mathrm{~m}$ alt., Ignatov \# 97-101 (MHA). Primorsky Territory: Chuguevka Distr., Verkhne-Ussuriskij station, 28.VIII.1974 Cherdantseva s.n. (VLA, LE); Ol'ga Distr., Vladimir Bay, Rakushka Settlement, 4.IX.1977 Bardunov s.n. (LE); Ussurijsk Distr., upper course of Suputinka River, 22.X.1934 Lazarenko s.n. (IRK, LE); Partizansk Distr., Olkhovaya Mt., Ignatov et al. \#06-2398 (MHA); Sikhote-Alinskij Reserve, Iman River Basin, Sibichi Settlement, 7.IX.1946 M.V.\& A.A. Korchaginy s.n. (LE); Sikhote-Alinskij Reserve, Kolumba River Basin, 26.VI.1984 Cherdantseva s.n. (LE); Shkotovskiy Distr., Lutanga River Basin, Kharitonovka Village, IX.1929 Transhel' s.n. (LE); Khasan Distr., Kedrovaya Pad' Reserve, 9.X.1954 Vasil'eva s.n. (LE).

Previous records of Stereodon fauriei from Kuznetskij Alatau, Southern Siberia (Pisarenko, 2004) were based on misidentification.

Distribution. Stereodon fauriei is known from Japan, Korea, China, the Asian Russia. In Russia this species is rather common in the south of the Far East; few localities are known from southern Siberia. It grows in deciduous, coniferous and mixed forests on rotten logs, stumps and projecting roots.

Differentiation. Stereodon fauriei is close to S. fertilis (Sendtn.) Lindb. According to Ando and Schofield (1999) and also to our data it differs from the latter species in (1) stem leaves more widely lanceolate, $1.4-2.5 \times 0.4-0.8 \mathrm{~mm}$, with width/length ratio $0.28-0.35$ (vs. stem leaves 1.4-2.5 x $0.35-0.5 \mathrm{~mm}$, width/length ratio $0.20-0.25$ in S. fertilis); (2) median laminal cells shorter, 50-80 $\mu \mathrm{m}$ (vs. (50-)60-100 $\mu \mathrm{m}$ ); (3) longer seta, $1.5-4.0 \mathrm{~cm}$ (vs. (1.0-)1.5-2.5 cm); (4) longer capsule, 2.0-3.0 mm (vs. 1.5-2.0 mm); (5) larger spores, 15-22(-24) $\mu \mathrm{m}$ (vs. (10-)13-18(-22) $\mu \mathrm{m})$. Stereodon fertilis is an European species, known in Russia from a few localities in the north-west of European Russia, Karelia and Pskov Province, and in the Caucasus, Kabardino-Balkaria (Afonina et al., 2006). Stereodon fauriei also resembles $S$. densirameus, but differs from the latter species by slightly larger plants, not so densely pinnate branching, and the alar group structure. This con- sists of more numerous comparatively large thinwalled hyaline cells and few small subquadrate supra-alar cells in $S$. fauriei vs. few large hyaline alar cells and more numerous small subquadrate supra-alar cells in S. densirameus. Ando (1957) noted also that capsules of $S$. fauriei are longer, usually more than $2.3 \mathrm{~mm}$, while capsules of $S$. densirameus never exceed $2.3 \mathrm{~mm}$.

5. Stereodon plumaeformis (Wilson) Mitt., J. Linn. Soc. Bot. 8: 154. 1865 Figs. 5, 7

Hypnum plumaeforme Wilson, Lonon J. Bot. 7: 277, t. 10-D. 1848.

Plants rather robust, yellowish-green to green. Stems prostrate, to $10 \mathrm{~cm}$, red-brown; usually regularly pinnately branching; hyalodermis absent, thick-walled cortical cells in 4-5 layers; central strand slightly developed. Branches $5-15 \mathrm{~mm}$ long, slightly complanate. Pseudoparaphyllia few, filamentous to lanceolate. Stem leaves 1.5-3.0 x $0.65-1.0 \mathrm{~mm}$, falcate-secund, broadly ovate at base, somewhat rounded to cordate at insertion, and rather abruptly narrowed into lanceolate acumen, slightly plicate; margins plane, serrulate; costa double, distinct. Branch leaves similar but smaller, 1.4-2.1 x 0.5-0.8 mm. Laminal cells linear, 50-70 x 4-5 $\mu \mathrm{m}$, with protruding upper angles on dorsal and ventral sides; basal cells more thick-walled and porose, sometimes yellow or brownish-yellow; alar cells enlarged, thin-walled, hyaline, supra-alar cells in 2-4 rows, small, subquadrate, thick-walled, sometimes supra-alar cells are numerous and form a well-delimited area. Dioicous. Perichaetial leaves erect, to $3.5 \mathrm{~mm}$ long, lanceolate, with long serrate acumen, strongly plicate; costa indistinct. Seta yellowish-red to reddish-brown, $2.0-5.0 \mathrm{~cm}$. Capsule $2.2-3.0 \mathrm{~mm}$ long, inclined, oblong, arcuate. Operculum conicapiculate or obtuse. [Exostome teeth to $0.85 \mathrm{~mm}$ long; yellowish-brown below, basal membrane of endostome extending to $1 / 3$ the length of exostome teeth; cilia 2-3. Spores 12-18 $\mu \mathrm{m}$.] (Description of sporophyte is given according to Ando, 1958 and Noguchi, 1994).

SPECIMENS EXAMINED: Primorsky Territory. Ol'ga Distr., Kit Bay near Glazkovo, Ignatov \# 07-2 (MHA); Lazo Distr., vicinity of Preobrazheniye Settlement, 23.VIII.1986 Cherdantseva s.n. (VLA, LE); Lazo Distr., Uglovaya Bay, 26.IX.1988 Cherdantseva s.n. (VLA, LE); Lazo Distr., Kievka, IX.1993 


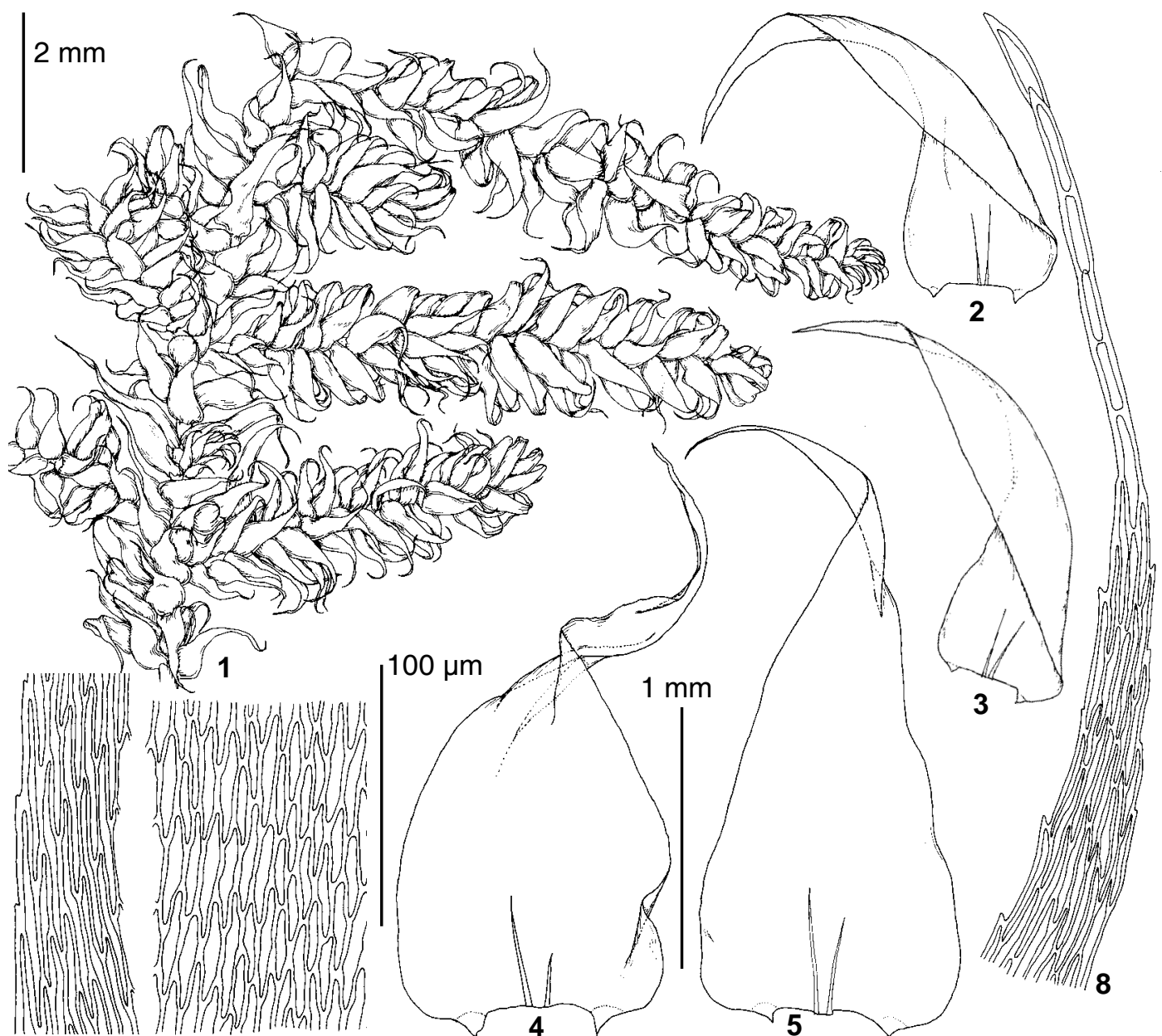

6

7

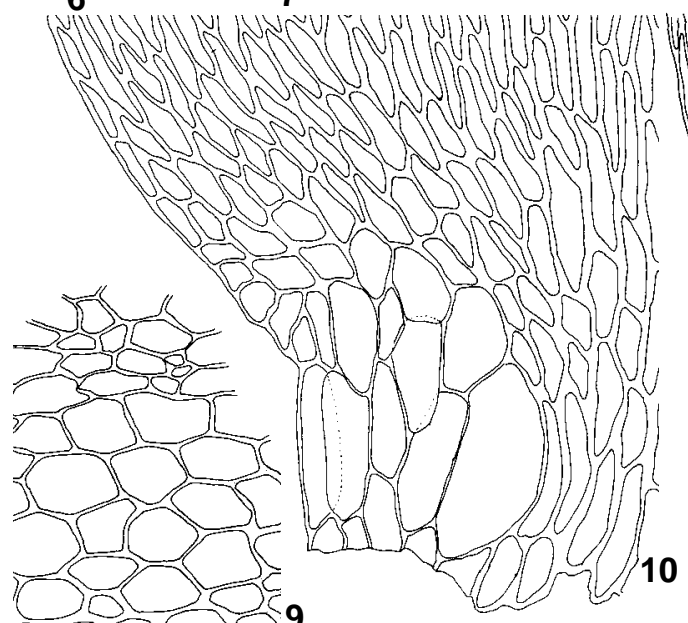

9 Fig. 5. Stereodon plumaeformis (Wilson) Mitt. (from Crimorsky Territory, Kit Bay, Ignatov \#07-2): 1 - habit; 2-3 $38980985 \mathrm{C}$ branch leaves; 4-5 - stem leaves; 6-7 - median leaf cells; 8 $2089808 \mathrm{C}$ upper leaf cells; 9 - stem cross section; 10-11-basal leaf cells.

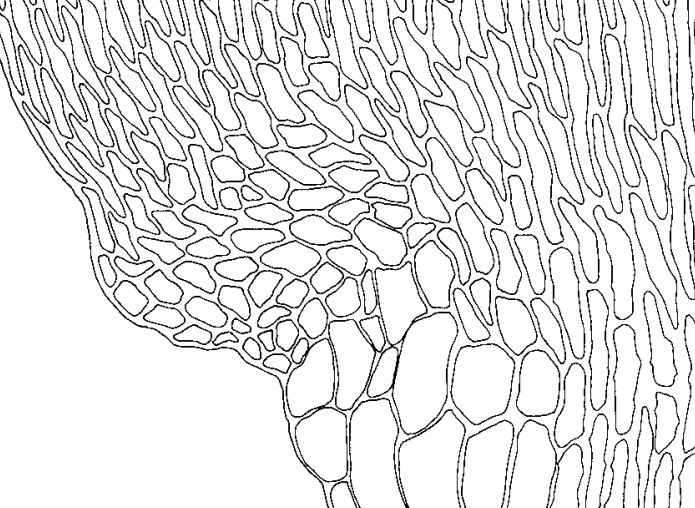

8080.8080 .6 Scale bars: $2 \mathrm{~mm}$ for $1 ; 1 \mathrm{~mm}$ for $2-5 ; 100 \mu \mathrm{m}$ for $6-11$. 


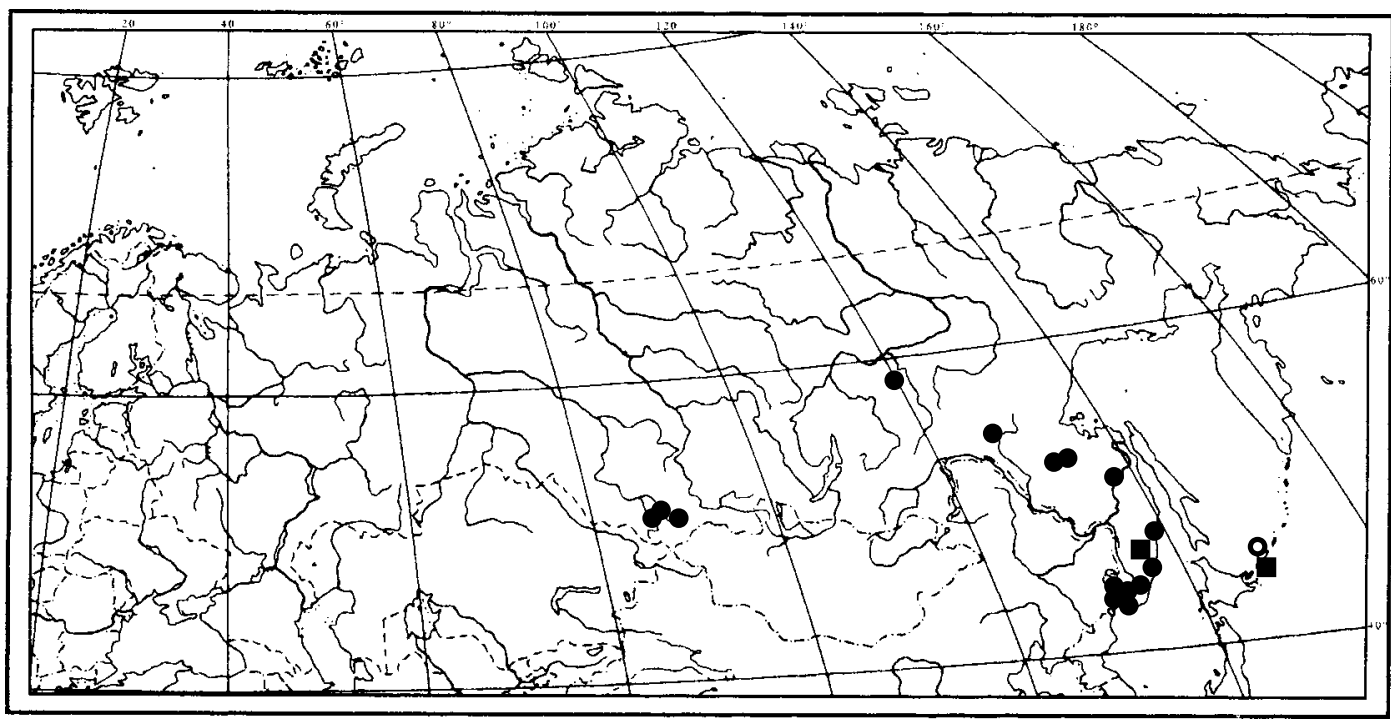

Fig. 6. The distribution of Stereodon fauriei (solid circles), S. dieckei (open circle) and S. densirameus (squares) in Russia.

Cherdantseva s.n. (VLA, LE). Khasan Distr., "Kedrovaya Pad' Reserve, 12.VI.1954 Vorobjev s.n. (VLA, LE); same, 1959 Ardeeva s.n. 12, 14 (LE); same, 16.X.1974 Bardunov s.n. (LE); Khasan Distr., Gromov Peninsula, Spaseniya Bay, 10.VI.1993 Cherdantseva s.n. (VLA, LE); Reineke Island, 20.IX.1997 Gorobets s.n. (LE). Magadan Province. Upper course of Kolyma River, Sibit-Tyellah Settlement, 17.VIII.1976 Blagodatskih s.n. (LE).

Distribution. Stereodon plumaeformis is common in Japan (Hokkaido, Honshu, Shikoku, Kuyshu, Ryukuy), it is also known in Korea, Taiwan, China, Himalaya, Indo-Chinese Peninsula and Hawaii. In Russia this species occurs mostly in Primorsky Territory; one plant was found among Lyellia aspera in the specimen from Magadan Province. Abramova \& Abramov (1975) reported Stereodon plumaeformis for the Caucasus (Botanical Garden of Batumi, Georgia), where it probably was occasionally introduced from East Asia with vascular plants. It grows on bases of tree trunks and on rocks.

Differentiation. Stereodon plumaeformis is easily recognized by its robust habit, stem without hyalodermis, leaves broad and more or less cordate at base. In habit $S$. plumaeformis resembles Calliergonella lindbergii; however it differs from the latter species by the longer and more narrow leaf acumen, less differentiated hyaline alar cells, laminal cells with protruding upper angles, and absence of stem hyalodermis. The difference from $S$. calcicola is discussed under that species.

Stereodon plumaeformis is a very polymorphous species. Specimens collected by Ignatov in Primorsky Territory (Partizansk Distr., Lozovyj Range, Chadolaz Mt., \# 06-2762, 06-2776, 06-2793) show some similarity to var. minus, which differs from the type variety in its smaller size, creeping stems, shorter and usually almost straight leaf acumens (Ando, 1958). But the specimens from Primorsky Territory are very poor and have stem leaves more or less falcate.

\section{KEY FOR IDENTIFICATION OF STEREODON AND SIMILAR SPECIES IN RUSSIA}

1. Epidermal cells well differentiated in stem cross-section, enlarged, hyaline and thinwalled, or partially differentiated, seen only in places

- Epidermal cells in stem cross-section not differentiated (sometimes large thin-walled cells of the alar group remain on the stem resembling a hyalodermis in stem cross-section ) ......... 16

2. Plants usually large; epidermal cells in stem cross-section well differentiated, enlarged, hyaline and thin-walled; leaves $2.0-3.5 \mathrm{~mm}$ long, weakly falcate, shortly and broadly acuminate

— Plants medium-sized or small; epidermal cells 


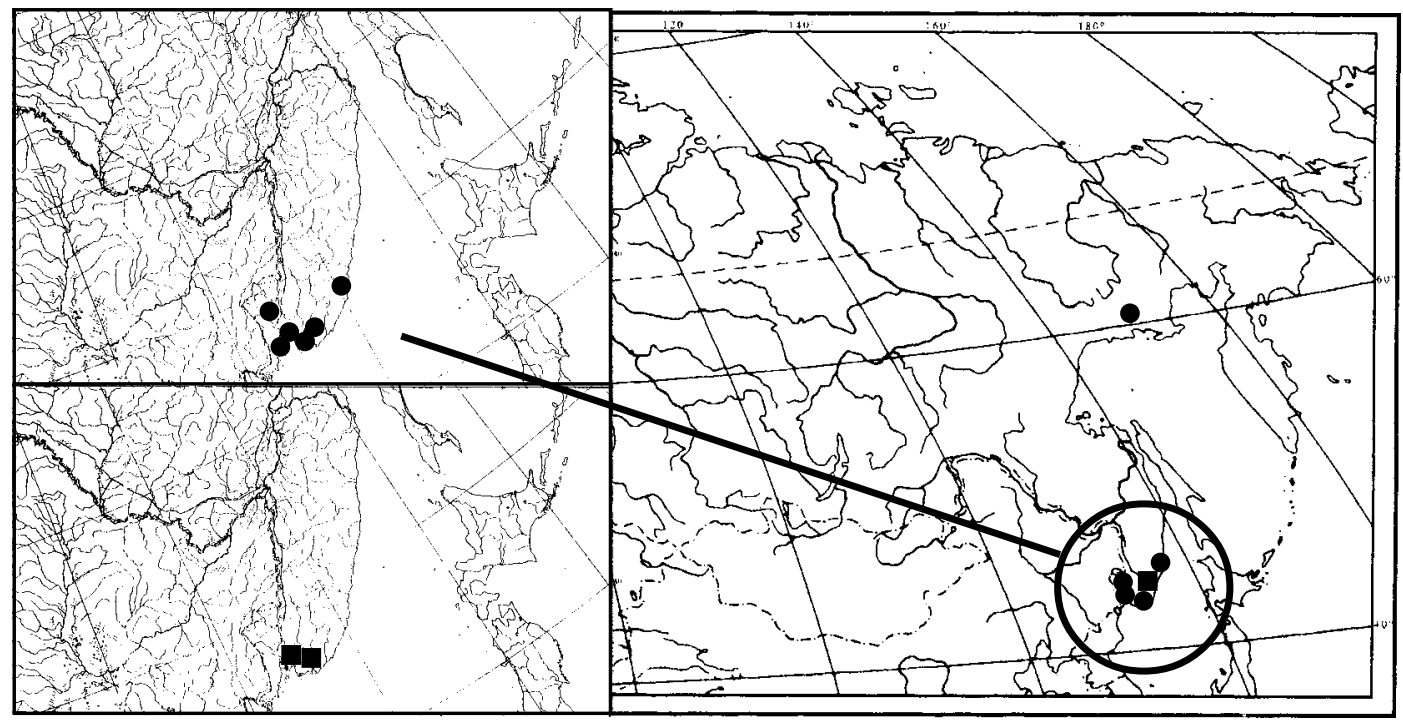

Fig. 7. The distribution of Stereodon plumaeformis (circles) and S. calcicola (squares) in Russia.

in stem cross-section well differentiated or seen only in places; leaves usually less than $2.0 \mathrm{~mm}$ long, \pm distinctly falcate to circinate, longly and narrowly acuminate 4

3. Shoots weakly complanate; alar group sharply delimited, consisting of large and thin-walled ovate cells; hygrophyte (grows in wet habitats) Calliergonella lindbergii

- Shoots clearly complanate; alar group weakly delimited, consisting of small subquadrate or short-rectangular cells with moderately thickened walls; mesophyte

Bredleria pratensis

4. Plants green-brownish to red-brownish; epidermal cells in stem cross-section well differentiated; cells at leaf insertion usually with red-brownish walls; leaf acumen rather short; spores 25-30 $\mu \mathrm{m}$; grows in wet places

Stereodon dieckei

- Plants usually green or yellowish-green; epidermal cells in stem cross-section well differentiated or weakly differentiated, seen at places; cells at leaf insertion usually with green or yellowish walls; leaf acumen more long and narrow; spores 12-15 $\mu \mathrm{m}$; grow in rather dry habitats

5. Autoicous; hyaline epidermal cells in stem cross-section usually partially differentiated, seen in places, rarely rather well differentiated (S. fauriei)
- Dioicous; hyaline epidermal cells in stem cross-section well differentiated 8

6. Plants small; stems regularly and very densely branching; stem leaves less than $2 \mathrm{~mm}$ long; alar group consisting of few oblong hyaline cells and numerous small, subquadrate, thickwalled supra-alar cells

Stereodon densirameus

- Plants medium-sized; stems regularly but less densely branching; stem leaves sometimes $>2$ $\mathrm{mm}$ long; alar group consisting of more numerous large, thin-walled cells and few small supra-alar cells

\section{7}

7. Laminal cells (40-)50-80 $\mu \mathrm{m}$ long; seta 1.4$4.0 \mathrm{~cm}$ long; capsule usually more than 2.3 mm long; species mainly with East Asian Atlantic-North American distribution

Stereodon fauriei

- Laminal cells (50-)60-100 $\mu \mathrm{m}$ long; seta 1.5$2.5 \mathrm{~cm}$ long; capsule usually to $2.0 \mathrm{~mm}$ long; species with European distribution

Stereodon fertilis

8(5).Central strand lacking; alar group consisting of few large and inflated "bubble-like" cells with moderately thickened walls and few smaller supra-alar cells; capsules almost erect to somewhat inclined

- Central strand present; alar group with different structure; capsules inclined or horizontal 
9. Leaves rather abruptly narrowed to the insertion; supra-alar cells 1-2(-3) along margin; endostome cilia 1-2, usually well developed or occasionally rudimentary

\section{Pylaisiadelpha tristoviridis}

- Leaves slightly narrowed to the insertion; supra-alar cells (2-)3-7 along margin; endostome cilia none

Pylaisiadelpha tenuirostris

10. Stem leaves triangular-lanceolate, rather markedly and usually strongly rounded to cordate at the insertion; leaf margins plane; alar group rather well differentiated, consisting of small thick-walled cells ......... Stereodon plicatulus

- Stem leaves ovate-lanceolate, not or weakly narrowed to the insertion; leaf margins recurved proximally; alar group with different structure 11

11. Stem leaves not narrowed to the base; margins recurved from base to the middle of leaf or higher; alar group weakly delimited, consisting of few larger rectangular cells with moderately thickened walls and 1-2 hyaline cells at extreme angles 12

- Stem leaves slightly narrowed to the base; margins plane; alar group either well delimited, inflated, consisting of large hyaline thin-walled cells or rather weakly delimited, not inflated, consisting of rectangular and quadrate cells with moderately thickened walls ...................... 14

12. Plants small; stem leaves $0.8-1.2(-1.5) \times 0.4-$ $0.5 \mathrm{~mm}$, not or very weakly plicate; laminal cells 25-40(-60) x 3-6 $\mu \mathrm{m}$.... Stereodon hamulosus

- Plants medium-sized; stem leaves 1.5-2.8 x 0.4$0.5 \mathrm{~mm}$, plicate; laminal cells $40-100 \mu \mathrm{m} . . .13$

13. Leaf margins distinctly and narrowly recurved from base to mid-leaf or higher; costa usually weakly differentiated, short; capsule 2.5-3.0(-5.0) $\mathrm{mm}$

Stereodon subimponens subsp. subimponens

- Leaf margins usually weakly recurved only at leaf base; costa distinct, rather strong, quite often reaching mid-leaf; capsule ca. $2.0 \mathrm{~mm}$ Stereodon subimponens subsp. ulophyllum

14. Alar group weakly delimited, consisting of subquadrate to rectangular cells, with few lower cells thin-walled and hyaline
- Alar group sharply delimited, consisting of large, thin-walled, hyaline cells ............. 15

15. Stem leaves (1.2-)1.6-2.5(-2.8) x 0.5-0.8 mm; laminal cells (50-)60-80(-90) x 3-4 $\mu \mathrm{m}$; alar group seen at least in some leaves

[Stereodon callichrous subsp. callichrous]

- Stem leaves (1.0-)1.2 -1.7(-2.0) x 0.4-0.6 mm; laminal cells 50-70(-80) x 3-4 $\mu \mathrm{m}$; alar group seen in most leaves

Stereodon callichrous subsp. japonicus

16 (1). Stem leaves cordate-auriculate or subcordate, \pm rounded at the insertion 17

- Stem leaves not cordate, rounded or almost not rounded at the insertion 20

17. Stem leaves cordate-auriculate at the insertion; alar group indistinctly delimited, consisting of numerous round-quadrate, thickwalled cells, laminal cells without papillae at upper ends Stereodon procerrimus

- Stem leaves subcordate or \pm rounded at insertion; alar group distinctly delimited, laminal cells with papillae at upper ends ...... 19

19. Plants robust; stems to $10 \mathrm{~cm}$; alar group consisting of large, thin-walled, hyaline cells and small supra-alar cells ... Stereodon plumaeformis

- Plants medium-sized or small; stems to 3-4 cm; alar group of stem leaves usually brown-colored, consisting of subquadrate to rectangular thick-walled cells and 1-2 larger, hyaline cells at extreme angles Hypnum saitoi

20(16). Leaf margins recurved; alar group consisting of small thick-walled, not brown-coloured cells 21

- Leaf margins plane; alar group with different structure 23

21. Dioicous; leaves plicate; margins strongly revolute from leaf base to near apex Stereodon revolutus

- Autoicous; leaves not or somewhat plicate; margins narrowly recurved at base, sometimes to the middle of leaf .....

22. Plants medium-sized; leaf margins distinctly serrulate; alar cells numerous, subquadrate or transversely rectangular, $8-15$, rarely 20 along leaf margin, well delimited; pseudoparaphyllia few, lanceolate; epiphytic species, growing mainly on tree trunks

Stereodon pallescens 
- Plants small; leaf margins almost entire to finely serrulate; alar cells less numerous, subquadrate, 4-10 along leaf margin, weakly delimited; pseudoparaphyllia numerous, subulate; epilithic species

Drepanum recurvatum

23. Autoicous; plants rather robust; stem strong, usually red-brown; stem leaves 2.0-2.5 mm long; alar group well delimited, consisting of large hyaline cells and smaller thick-walled supra-alar cells; calcicolous, epilithic

Stereodon calcicola

- Dioicous; plants medium-sized or small; alar group consisting mainly of thick-walled cells

24. Stems usually fastigiately or irregularly branching; sometimes only with a few short branches or almost simple; laminal cells with incrassate, porose walls; alar group wellmarked, excavate, brown-colored, consisting of rounded-quadrate (upper) to rectangular (lower) cells with incrassate and porose walls Stereodon bambergeri

- Stems regularly or irregularly but rather strongly branching; laminal cells with moderately thickened walls; alar group weakly excavate or not excavate

25. Alar group moderate, consisting of rather numerous subquadrate, usually orange-brown colored cells with moderately thickened walls and a few lowermost cells hyaline and thinwalled; pseudoparaphyllia large, broadly lanceolate, sometimes lobed and incised, with ciliate points Hypnum imponens

- Alar group rather large, clearly delimited, consisting of numerous quadrate thick-walled cells or with a few lowermost cells hyaline and thin-walled; pseudoparaphyllia semicircular or lanceolate to filamentose, not lobed or incised 26
26. Leaves abruptly acuminate; median laminal cells 30-50 $\mu \mathrm{m}$ long, with obtuse ends; pseudoparaphyllia semicircular or lanceolate to subfilamentose 27

- Leaves usually gradually tapering from base to apex; median laminal cells 50-80 $\mu$ m long; pseudoparaphyllia narrowly lanceolate to subfilamentose 28

27. Leaves loosely imbricate, only in extreme conditions densely imbricate and julaceous; pseudoparaphyllia semicircular to round-rectangular; alar group consisting of subquadrate cells, 10-16(-20) along leaf margin

Stereodon vaucheri

- Leaves always densely imbricate; pseudoparaphyllia lanceolate to subfilamentose; alar group extending to $1 / 3$ the leaf length, consisting of subquadrate, transverse-rectangular or irregular cells, 50-60 along leaf margin ... Eurohypnum leptothallum

28. Plants pale green; stems regularly pinnately branching, branches strongly complanate; alar group consisting of a few lowermost cells hyaline and much enlarged and numerous small subquadrate thick-walled cells Hypnum jutlandicum

- Plants dark green, yellowish or brownish; stems less regularly or irregularly pinnately branched, branches weakly complanate to julaceous; alar group more or less homogenous, consisting of subquadrate thick-walled cells

Hypnum cupressiforme

\section{ACKNOWLEDGEMENTS}

We are grateful to L.V. Bardunov, V.Ya. Cherdantseva, M.S. Ignatov and E.I Ivanova for arranging loans from IRK, VLA, MHA, and SASY, respectively, and to A. Newton for the correction of English. The work was partly supported by RFBR 05-04-48705 and HШ-7063.2007.4.

\section{LITERATURE CITED}

[[AFONINA, O.M.] АФОНИНА О.М. 2004. Виды Нурnum секции Hamulosa (Musci, Hypnaceae) в России. - [Нyрnum sect. Hamulosa (Musci, Hypnaceae) in Russia] Arctoa 13: 9-28.

[AFONINA, O.M. \& V.Ya. CHERDANTSEVA] АФОНИНА О.М., В.Я. ЧЕРДАНЦЕВА 2007. Stereodon calcicola (Pylasiaceae, Musci) в России. - [Stereodon calcicola (Pylasiaceae, Musci) in Russia] Бот. журн. [Bot. Zhurn.] 92(11): 1760-1763.
[AFONINA, O.M., E.A. IGNATOVA \& A.I. MAKSIMOV] АФОНИНА О.М., Е.А. ИГНАТОВА, А.И. МАКСИМОВ 2006. Stereodon fertilis (Pylaisiaceae, Musci) в России. [Stereodon fertilis (Pylaisiaceae, Musci) in Russia] Бom. журн. [Bot. Zhurn.] 91(2): 329-335.

ANDO, H. 1956. The Hypnum species restricted to Japan and adjacent areas. - J. Sci. Hiroshima Univ. Ser. B, Div. 2 (Botany). 7: 143-152. 
ANDO, H. 1957. The Hypnum species restricted to Japan and adjacent areas (2). -J. Sci. Hiroshima Univ. Ser. B, Div. 2 (Botany). 8: 1-18.

ANDO, H. 1958. The Hypnum species restricted to Japan and adjacent areas (3). -J. Sci. Hiroshima Univ. Ser. B, Div. 2 (Botany). 8: 167-208.

ANDO, H., \& W.B. SCHOFIELD 1999. Hypnum fauriei, not H. fertile (Hypnaceae, Bryopsida), in eastern North America. - Bryobrothera 5: 49-54.

[BARDUNOV, L.V. \& V.Ya.CHERDANTSEVA ] БАРДУНОВ Л.В., В.Я. ЧЕРДАНЦЕВА 1982. Листостебельные мхи Южного Приморья. - [Mosses of the South of Prmorsky Territory] Новосибирск, Наука [Novosibirsk, Nauka], 208 c.
[IGNATOV, M.S. \& E.A. IGNATOVA] ИГНАTOB M.C., E.A. ИГНАТОВА 2004. Флора мхов средней части европейской России. Т. 2. - [Moss flora of the Middle European Russia. Vol. 2] M., KMK [Moscow, KMK]: 609-960.

IGNATOV, M.S. \& O.M.AFONINA (eds.) 1992. Check-list of mosses of the former USSR. - Arctoa 1: 1-85.

IGNATOV, M.S., O.M.AFONINA, E.A. IGNATOVA et al. 2006. Check-list of mosses of East Europe and North Asia. - Arctoa 15: 1-130.

NOGUCHI, A. 1994. Illustrated moss flora of Japan. Pt. 5. Hattori Botanical Laboratory, Nichinan: 1013-1253.

PISARENKO, O.Yu. 2004. Mosses of the central part of Kuznetskiy Alatau (Southern Siberia). - Arctoa 13: 241-260. 